\title{
The Growth Performance Evaluation of Cattle Breeds in the South Western Agro-Ecological Zone (SWAEZ) of Uganda
}

\author{
Charles Lagu1, Robert Nsubuga Mutaka1, James Oluka², \\ Steven Byenkya1, Betty Laura Ayoo1, \\ Immaculate Nabukenya ${ }^{1}$ and Proscovia Ntakyo $^{1}$ \\ ${ }^{1}$ Mbarara Zonal Agriculture Research and Development Institute, Mbarara, \\ 2National Livestock Resources Research Institute (NaLIRRI), Tororo, \\ Uganda
}

\section{Introduction}

Agriculture is Uganda's most important sector, contributing $48 \%$ of gross domestic product (GPD) and directly supporting $85 \%$ of the population in rural areas. Livestock which is concentrated along 'the cattle corridor' runs southwest to northeast across Uganda, encompassing 29 districts represents $7.5 \%$ of the GDP and $17 \%$ of the agricultural GDP. The south-western agro-ecological zone (SWAEZ) of Uganda, comprising of the districts of Bushenyi, Ibanda, Isingiro, Kiruhura, Lyantonde, Mbarara, Ntungamo, Rakai and Sembabule lies within the corridor with a population of 3,085,900 people (UBOS 2006).

The cattle population in the SWAEZ number to 1,689,605 (UBOS and MAAIF, 2009). There are a number of different cattle breeds on farms in the south western agro-ecological zone (SWAEZ) which include the following: Friesian and Friesian crosses 50\% (F1) and $75 \%(\mathrm{~F} 2)$, Boran and Boran crosses and the Ankole cattle. The Ankole cattle used to be the most predominant breed of cattle but they have been extensively crossed with the Friesian cattle.

There are generally no guidelines on the optimum productivity and cost-effective level at which to stop cross-breeding. It is known that the more one up-grades the more susceptible the crossbred animals become to common diseases requiring extra cost on feeding and disease control. Studies by Kiwuwa et al 1983; Kugonza (2005) and Ndumu (2007) indicate similar findings about the production and husbandry constraints affecting other local breeds, the Ankole cattle in addition to extensive nature of cross breeding of the Ankole cattle. But these evaluations have been limited in scope and approaches while covering limited agro-ecological environments and unique production systems and furthermore, there have been a lot of changes in the grazing systems, feed resources availability and supply as a result of continued adverse changes in climatic conditions which impacts on the overall performance of the animals. It is, therefore, necessary that up-to date information is constantly generated to guide farmers in the best practices with regards to adoption of 
appropriate breeding and production technologies for improving production and productivity of various cattle breeds in Uganda.

The overall objective of the study was to evaluate and document the performance of existing breeds of cattle in the south western agro-ecological zone (SWAEZ) for improved livestock productivity. The specific objectives include: (i) to evaluate the growth performance of existing cattle breed under on-station and on-farm conditions.

The study is meant to generate up to-date and accurate information on performance of selected cattle populations in the SWAEZ in terms of their growth, maturity and production parameters. This would help in packaging of appropriate information on better management practices to guide farmers in partnership with National Agriculture Advisory Services (NAADS) and extension workers as conduits for effective uptake pathways for technology adoption.

\section{Materials and methods}

A longitudinal study involving growth data collection from Ankole, Friesian, Friesian cross, Boran and Boran crosses was conducted. Growth data on-station and on-farm from the experimental animals was collected over a period of three years (July 2006 to June 2009) and 9 months from October 2008 to June 2009 respectively.

The on farm study was conducted in the districts of Kiruhura, Ibanda and Sembabule. In Kiruhura district, the sub-counties of Kikatsi and Sanga were involved. In Ibanda district, Nyabuhikye and Kikenkye sub-counties were involved. In Sembabule the studies were conducted in Lugusulu and Migwala sub-counties.

On-station the studies were conducted at Mbarara Zonal Agriculture Research and Development Institute (ZARDI) found in Mbarara district. It involved taking bi- weekly (i.e. fortnightly) weights using the heart girth tape. The heart girth tape was graduated in both $\mathrm{cm}$ and $\mathrm{kg}$. Both measurements were taken but for purposes of analysis, only weight values were used. There was a high and positive correlation between heart girth and body weight of cattle (Oluka, 2006). Individual study animals were identified using the ear tag numbers for effective continuous monitoring. Animals were restrained in the crush and weighed using the heart girth tape.

The sample sizes varied from district to district. In Kiruhura district, the study animals were 141, Ibanda district, 182 and in Sembabule district 189. Calves below the age of three months were identified and randomly selected and tagged for the study. Only farmers who were willing to participate in the study were recruited and involved in the study. The farmers willingly gave the number of animals requested for the study. More Female animals were preferred because they were normally kept for longer periods by the farmers and were not easily sold. In contrast the male were sold off at any age to meet the financial needs of the farmers e.g. paying school fees, meet family health care needs or provide food.

Under on-station management, a total of 30 Ankole cattle and 35 Friesian cattle were recruited for the study. Unlike the on-farm cattle, parameter measurement and data collection started immediately after birth of calves by taking and recording birth weights and there after bi-weekly. 
The heart girth tape was placed around the girth for reading off the weights. Weights of cattle were immediately recorded in data sheets and transferred for entry into Excel programme as back up and for further collation for analysis; all weights in kilograms $(\mathrm{kg})$ were entered in Excel worksheet

\subsection{Description of on-station data}

On-station data involved only two cattle breeds i.e., the pure (100\%) Friesian and the pure $(100 \%)$ Ankole cattle. The weights were taken immediately after birth. The sample sizes were 30 Ankole cattle and 35 Friesian cattle. Continuous recording of heart girth and body weight measurements was done every two weeks for a period of 3 years. The data was, however entered in Excel at interval of 30 days i.e. monthly 1 for period 1-30 days, period 2 for 31-60 days, etc. All calves were managed under similar conditions allowing suckling up to 6 months while their dams were on open free range grazing management under the care a herdsman. Comparison was based on fixed effects under a single management of one onstation site focussing on breed differences.

Prior to the analysis of variance (ANOVA), a simple descriptive statistical analysis was done to examine the distribution of weight data structured at 30-day intervals for distribution of the means. Those values showing gross errors and outlying were excluded from the data set to avoid adversely affecting the means and hence, standard deviations, variances and standard errors. This was achieved using VIEWTABLE, GPLOT and MEANS procedures of SAS, version 9 (2002). The GPLOT showed the distribution of observations against the different time intervals of 30 day means.

\subsubsection{Analysis models}

ANOVA using General Linear Model (GLM) (SAS, 2000) for calf body weight was performed to determine the fixed effects of various factors on body weight at 30-day intervals from the first month of birth to $12^{\text {th }}$ months of age (360 days of age ). The data was classified according to the experimental variables covering the twelve periods 1-30, 31-60, 61-90, 91-120, 121-150, 151-180, 181-210, 211-241, 241-270, 271-300, 301-330 and 331-360 days (Table 1).

Various analyses were run for different combination of the fixed effects and effects with non-significance levels of $\mathrm{P}>0.05$ dropped from the next test model until the final model was developed. After final adjustments for the various differences and exclusions of nonsignificant effects such as year of birth and multiple births and interaction of cattle breed with season of birth, the final model (i) below was arrived at. This includes only the effect of breed, sex of calf and season of birth (model i) below.

$$
\mathrm{Y}_{i j k l}=\boldsymbol{\mu}+\mathbf{B}_{i}+\mathbf{X}_{j}+\mathbf{S}_{k}+\mathrm{e}_{i j k l}
$$

Where:

$Y_{i j k l m}=$ the live weight of the $1^{\text {th }}$ calf born under $i^{\text {th }}$ calf cattle breed, $j^{\text {th }}$ sex of calf and $k^{\text {th }}$ season of birth.

$\boldsymbol{\mu}=$ the common parameter (konstant)

$\mathbf{B}_{i}=$ the fixed effect of breed of cattle $(i=1,2)$ 
$\mathbf{X}_{j}=$ the fixed effect of sex of calf $(\mathrm{j}=1,2)$

$\mathbf{S}_{k}=$ the fixed effect of season of birth $(\mathrm{k}=1,2)$

$\mathbf{e}_{i j k l}=$ the random residual effect

\subsection{Description of on farm cattle data}

Cattle handling varied from farmer to farmer depending on availability of handling structures. In some cases the animals were put in a crush, restrained and weight measurement taken using the heart girth tape. In other cases, individual animals were restrained manually by field assistants using ropes. The heart girth and weight estimates were taken using the tape when the animal was calmed down and standing in an upright and straight position. The measurements were immediately recorded in field data sheets. Thereafter, the data was transferred into Excel for back up, collation and analysis.

On-farm data involved 4 genetic breeds of cattle including pure Ankole and Boran crossbred Friesian and Boran. It was, however difficult to determine the exact level of the crossbred animals. At the start of the field study, the calves that were 3 months old were recruited for measurements. However, with time, calves were born among the herds of the participating farmers. The measurements of such calves were recorded within the first month of birth. The heart girth and weights were again taken at the time of the next visit. This was done on monthly intervals though, in some cases, delays could occur due to late release of operational funds. The sample sizes were however larger than on-station with Kiruhura district offering 141 animal records, 182 in Ibanda district and 189 in Sembabule . Continuous recording of heart girth and body weight estimates was done for only 9 months due to the heavy expense and limited funding. All data was entered in Excel at 30 days intervals i.e. period 1 for 1-30 days, period 2 for 31-60 days, etc. All calves were managed under similar conditions allowing suckling up to 8-12 months or at the time when the farmers observe that the cow is nearing to calve down again. All experimental animals from the selected participating farmers were on free range management system under herding. The comparison was based on fixed effects under a free range management focussing on four cattle breed differences, that is Ankole, Boran, Boran $x$ Ankole, and Friesian $x$ Ankole.

Prior to the ANOVA was employed to examine the distribution of live body weight data structured at 30-day intervals. Those values whose means showed gross errors and outlying were excluded from the data set to avoid adversely affecting the means, standard deviations, variances and standard errors. This was achieved again by applying the VIEWTABLE, GPLOT and MEANS procedures of SAS (2002). The GPLOT showed the distribution of observations against the different time intervals of 30 day means.

\subsubsection{Analysis models}

ANOVA using General Linear Model (GLM) (SAS, 2000) for calf body weight was tested. This was done to determine the fixed effects of various factors on body weight at 30-day intervals from the first month of birth to 12 months of age (360 days). The data was classified according to the experimental variables covering the twelve months periods 1-30, 31-60, 61-90, 91-120, 121-150, 151-180, 181-210, 211-241, 241-270, 271-300, 301-330 and 331-360 days (Table 1). 
Various analyses were run for different combinations of the fixed effects. Those effects with non-significance levels at $\mathrm{P}>0.05$ were dropped from the next test model until the final model was developed. After final adjustments for the various differences and exclusions of non-significant effects such as year of birth, farmer herd and interaction of cattle breed with season of birth, the final model (i) below was arrived at; that included the fixed effects of breed, sex of calf, season of birth and district of birth (model ii) below.

$$
\mathrm{Y}_{i j k l m}=\boldsymbol{\mu}+\mathbf{B}_{i}+\mathbf{X}_{j}+\mathbf{S}_{k}+\mathbf{D}_{l}+\mathrm{e}_{i j k l m}
$$

Where:

$\mathrm{Y}_{i j k l m}=$ the live weight of the $\mathrm{m}^{\text {th }}$ calf born under $\mathrm{i}^{\text {th }}$ calf cattle breed, $\mathrm{j}^{\text {th }}$ sex of calf, $\mathrm{k}^{\text {th }}$ season of birth and $1^{\text {th }}$ district of birth

$\boldsymbol{\mu}=$ the common parameter (konstant)

$\mathbf{B}_{i}=$ the fixed effect of breed of cattle $(\mathrm{i}=1,2)$

$\mathbf{X}_{j}=$ the fixed effect of sex of calf $(j=1,2)$

$\mathbf{S}_{k}=$ the fixed effect of season of birth $(\mathrm{k}=1,2)$

$\mathbf{D}_{l}=$ the fixed effect of district of birth $(1=1,2,3)$

$\mathbf{e}_{i j k l m}=$ the random residual effect

\section{Results and discussions}

\subsection{Genetic group effect on body weight and daily gain for on-station and on-farm calves}

On station there was significant effect of breed on body weight of the cattle between month 1 and 2, then between the later months from month 7 to 12 (Tables $1 \mathrm{a}$ and $1 \mathrm{~b}$ ). The birth weights of the Friesian calves were higher than that of the Ankole (Table 2a). There was no significant difference in growth weight of both the Friesians and the Ankole up to six months. After the age of 6 months, the Ankole grew faster than the Friesian. This was attributed to the weaning shock that was experienced by the Friesian calves versus the Ankole that continued to suckle their dams. This is clearly illustrated in Fig. 1. This therefore explained the weight variation between the Friesian and Ankole after six months as illustrated in figure1. Animal used on the station were composed of an old stock that had been breeding for along time without replacement of bulls. This apparently introduced some element of inbreeding depression on the herd. The inbreeding could be an important factor that could be used to explain the variation in the growth rate. Furthermore, disease prevalence and worm burden were present on station; however, the Friesian calves were more susceptible to the diseases than the Ankole calves. The Friesian calves were intensively kept in paddocks compared to the Ankole calves which were moving with their dams. This increased the chances for the Friesian calves to pick worm eggs. These findings are similar to the results by Said at al., 2001 and Kugonza et al., 2005.

On farm the study found out that there was significant relationship between breed and growth rate $(\mathrm{p}<0.05)$ from the first month to the ninth months as illustrated in table $3 a$ and $3 \mathrm{~b}$. The growth weight of the Boran was much higher than for the Boran $x$ Ankole crosses and Friesian $x$ Ankole crosses respectively. This could be explained by the fact that the Borans had great potential for growth intensity traits, have high feed conversion efficiency, 


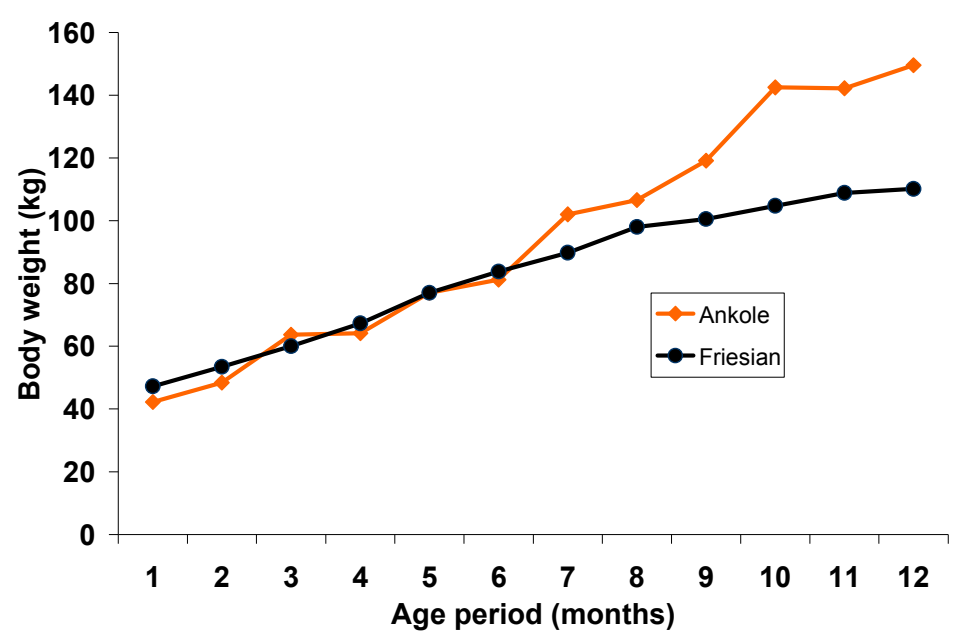

Fig. 1. On station graph for weights of Ankole and Friesian Crosses

were well adapted to the environment and resistant to harsh conditions (Ndumu, 2007). The dams of the Borans were not milked, therefore the calf got as much milk as it required for growth. Ankole on the other hand were dual purpose i.e. they were for both meat and milk production (Kugonza et al., 2005). This had effect on their growth pattern in terms of functional roles. The Ankole had low genetic potential were also well adapted to prevailing environmental conditions and exhibited better abilities to utilize low quality forages (Tuah and Yaa Nyamaa Danso, 1985; LRSP, 1999; Scerf, 2000 in Kugonza, 2005). The growth pattern of the Boran and Friesian crosses were lower compared to the pure breeds. This could be because of the following: high susceptibility to diseases, harsh environmental conditions, insufficient amounts of feeds during dry seasons, management related issues e.g. prophylaxis, deworming, and tick control (Moran, 2002; Asimwe and Kifaro, 2007). It was however difficult to determine the level of crossing since farmers had no records to substantiate the level of crossing among the breeds. Farmers had poor recording system and culture, information on the breeds was mainly got from memory and oral communication. This had challenges related to inaccuracy in records and hence human memory failure. These results were in agreement with those documented by Kugonza et al., 2004.

\subsection{Effect of sex on the growth weights of calves on station and on farm}

On station, there was a significant relationship between sex and body weight of Ankole and Friesian calves $(\mathrm{p}<0.05)$. The birth weight of both male and female were similar (Figure 2$)$. However, females' calves after the third month were heavier than the males. Similar studies by Vial, V. E. and More O'Ferrall G. J. (1965) had similar results. This could be explained as follows: large value in error variance, less managemental factors that were considered in the model during analysis, another reason could be castration stress that affects the males. This finding agrees with Fisher et al., 2001 where they established that banding or branding and surgical castration negatively affects growth rates of castrated bull calves. 


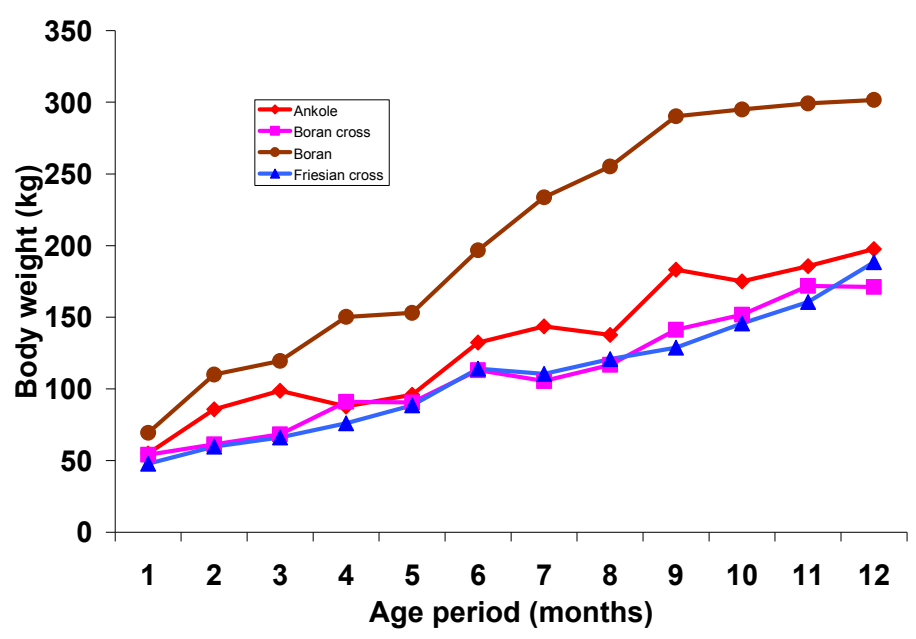

Fig. 2. Growth Patterns on breeds of Cattle in Kiruhura, Ibanda and Sembabule

On farm there was no significant relationshp between sex and growth weights $p>0.05$ among the breeds (table $3 \mathrm{a}$ and $3 \mathrm{~b}$ ). This could be explained by the fact that some factors in the model were not captured. The values taken were not large enough to distinctively give differences betweeen female and male animals, and probably sample size was small. However, from field experience, male calves were usually restricted from suckling unlike the females, this therefore counteracts hormonal effects. It is only when the male calves are intended for breeding that they get adequate milk. It becomes easy to distinguish between male calves intended for breeding to those left for slaughter. Female calves on the other hand were given preferential treatment because they were intended for breeding. Generally, female and male calves had competitive growth. These findings were in variation with the study by Krupá et al., 2005. They found out that calves sex and age of dam at calving jointly explained the highest proportion variability (56-75\%). Riha et al 1999 as cited in Krupá et al 2005 found out that birth weight of calves both male-singles and male twins had higher birth weights than femalesingles and female-twins. This particular study found out that twinning of cattle was a rear occurrence in Kiruhura, Ibanda and Sembabule. Riha et al., 1999 in Krupá et al., 2005 reported higher birth weights, weights at 120 days, weaning weights, and average daily gains for males and singles. Higher growth intensity in twins could be due to either a smaller number of twins involved in the analysis or to milk stealing behaviour of twin calves. In the study areas of Kiruhura, Ibanda and Sembabule, twinning hardly ever occurs and milk stealing behaviour was common among the Friesian crosses. In the Ankole, calf attachment to the dams is very strong as such; milk stealing behaviour was a rare phenomenon.

Goyache et al., 2003 reported the highest weaning weights for calves descending from seven to eleven years old dams. On the other hand, Pribyl et al., 2003 as cited in Krupá et al., 2005 reported highest weights in fastest growth for calves of seven to nine year old dams. Lowest weights were reported for calves of first primiparas (2 year olds or younger dams). This could be explained by the fact that young dams needed more nutrients to complete their own growth (Kifaro, 1984 and Katyega 1988). In comparison with mature dams, cows of higher age 
usually produce calves of lower birth weights as production abilities decreases along with the increasing age of the dam. The results in this study concur with the observations made by Krupá et al., 2005. In this study, insignificant differences between the male and female calf weights could be explained by the fact that sample sizes were small, higher variance ratios, high herd variability in both husbandry practices and geographical locations figure 5.

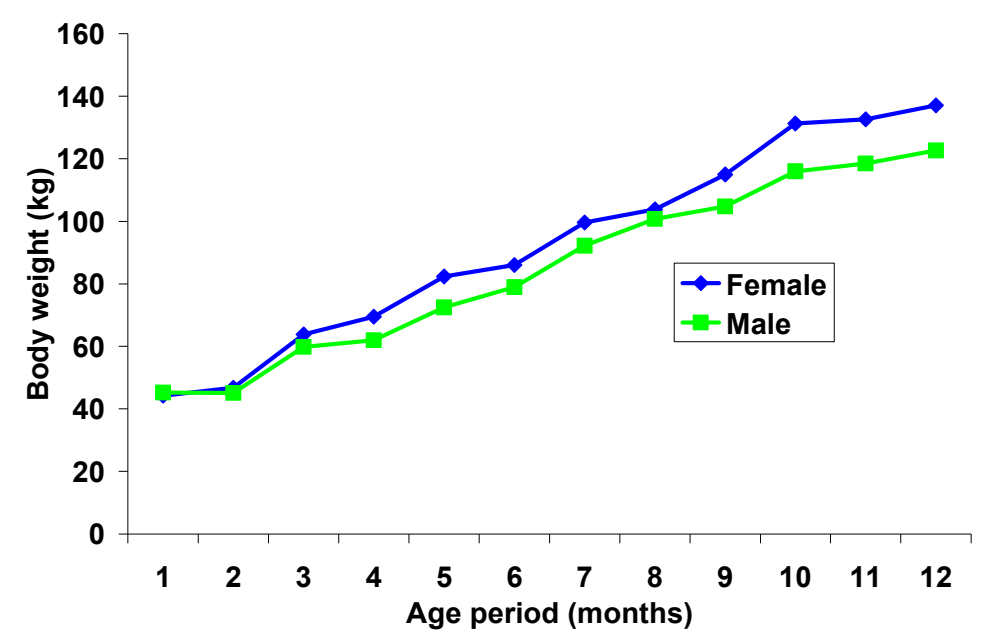

Fig. 3. On-station comparison of weights of Female and Male cattle

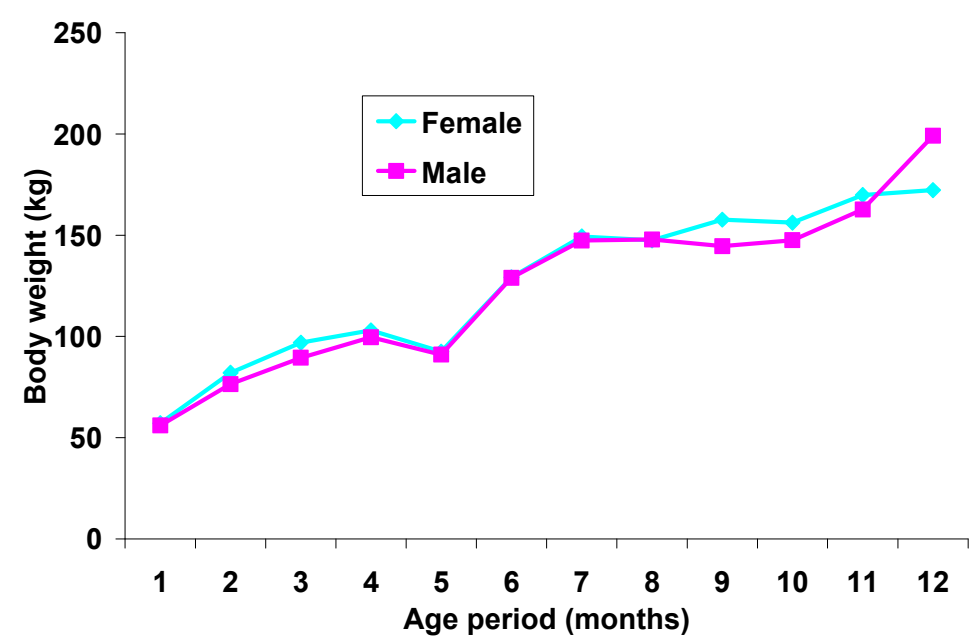

Fig. 4. On-farm comparison of weights of female and male cattle compared 


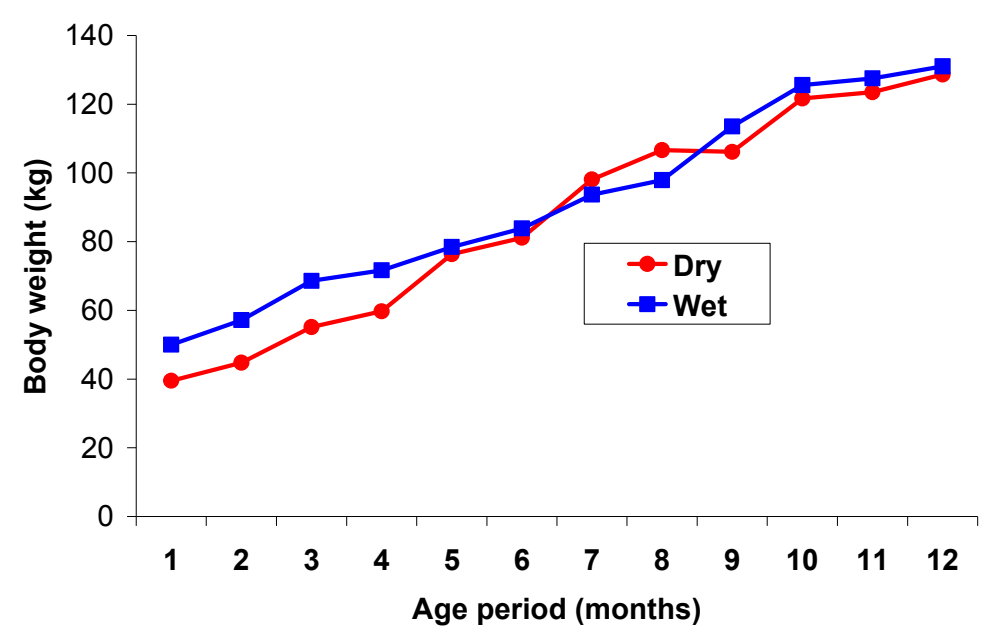

Fig. 5. On-station comparison of seasonal effects on cattle growth

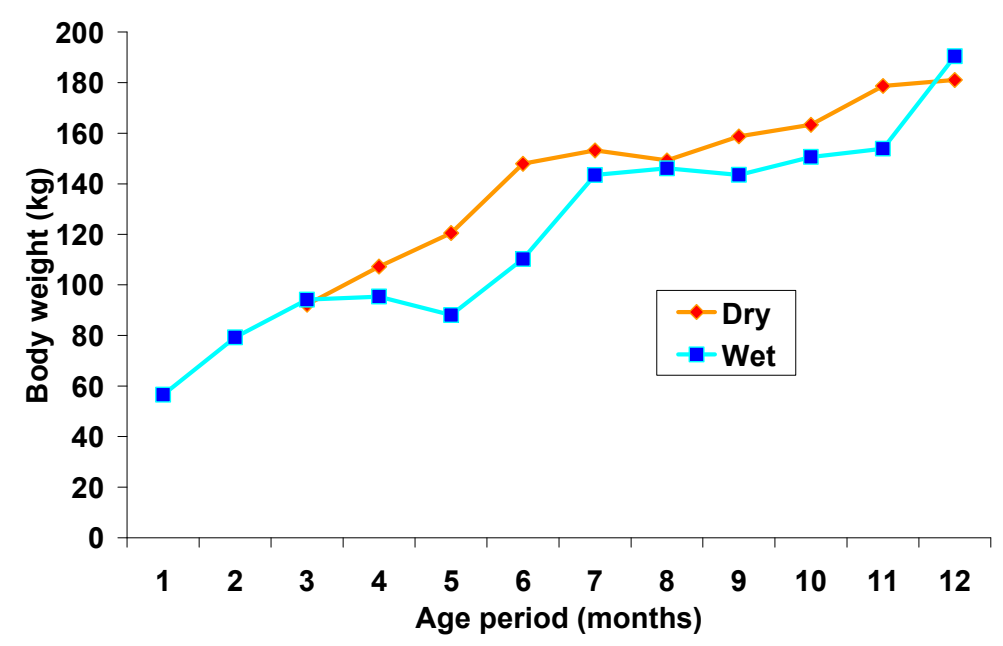

Fig. 6. Graph for weight Patterns of on farm Cattle and seasonal Variation

\subsection{Effect of season on the growth weights of calves on station and on farm}

On station, there was a significant relationship between season and body weight among Friesian and Ankole calves. In the first five months of neonatal life, calves weighed higher during the wet season than the dry season. This could be explained by fact that there was fodder availability during the wet season for the dam and the calf. The variation in body weight after the fifth month tends to fluctuate between the wet and dry season. During these periods, the calves had grown faster and had better adaptability and tolerance to fodder fluctuation. From six months onwards, there was increased resistance towards worm 
burden and other diseases hence explaining the fluctuation between the body weights during the wet and dry season. This finding agrees with observation made by Kugonza et al, 2005 and Twinamatsiko, 2001.

On farm there was significant relationship between season and the growth rate among the breeds in period four $(p=0.0059)$ table 3a. Calves born during the dry season weighed heavier than the calves born in the wet season. This was due to adequate forage availability for the dams during the rainy season (Twinamasiko, 2001). This therefore met the gestational needs of dams and the foetus especially during the last trimester. There was inadequate forage during the dry season, as such, the dams had inadequate amount of forage availability. However, calves born during the wet season were weaker than those born during the dry season. The ability of these calves to cope with the environmental conditions was compromised. This explained why calves born during the dry season would perform much better than those born during the wet season. Further still, calves born in the wet season would perform less compared to the ones born in the dry season. This could be explained by the fact that there was coldness predisposing calves to pneumonia, high worm burden, high tick challenge, presence of bacterial and protozoan diseases e.g. collibacillosis, coccidiosis, etc. all these factors negatively affect the growth of the calves during the wet season. This agreed with the report of LRSP, 1999. The lack of environmental modification impacts negatively on growth pattern of calves. During the dry season, grazing ruminants often show signs of distress with only short periods of grazing from mid morning to late afternoon. The restricted grazing is usually attributed to the direct effects of temperature and solar radiation on the animal. But this is not necessarily the case as climate forage interactions also contribute to animal distress (Anonymous, 1981).

High ambient temperatures ushered in rapid maturation of forages leading to a rise in cell wall content. The particular parts affected were the stems and leaves of the pasture grasses. There was a direct relationship between plant maturation and temperature rises, as such, forages matured fast and led to increase in cell wall content. The increase in cell wall content decreased the digestibility of the cell wall. As the ambient temperature rose, the digestibility of the dry matter of the forage decreased due to a rise in the cell wall content and decrease in digestibility of the cell wall (Minson and McLeod, 1970 in Anonymous 1981). On the other hand, high light intensity led to increase in the content of water soluble carbohydrates, whereas high temperatures decreased water soluble carbohydrates (Anonymous, 1981). This therefore meant there was low fodder availability, poor nutritional value of the fodder. The dams during dry season were deprived of requisite nutritional needs to meet the functional roles of maintenance and reproduction (Mc Donald et al., 2002).

\subsection{Effects of location on the weights of calves on-farm}

Generally, the study found that there was no significant differences between body weight of calves among the different district (Kiruhura, Ibanda and Sembabule) $(p>0.05)$ but there was significant relationship in the months $6(p=0.001)$ and months $8(p=0.0007)$. This could be explained by the fact that the three districts were located in the same agro ecological zone, and therefore, the, management husbandry related practices were similar basically extensive systems with minimum investment. The similar practices included grazing, deworming, spraying, etc. It was however noted that water was more available in Ibanda than in Kiruhura and Sembabule. In the dry season, animals in Kiruhura and Sembabule had to trek 
long distances in search for water for drinking. This finding agrees with study conducted by Nsubuga, 1996.

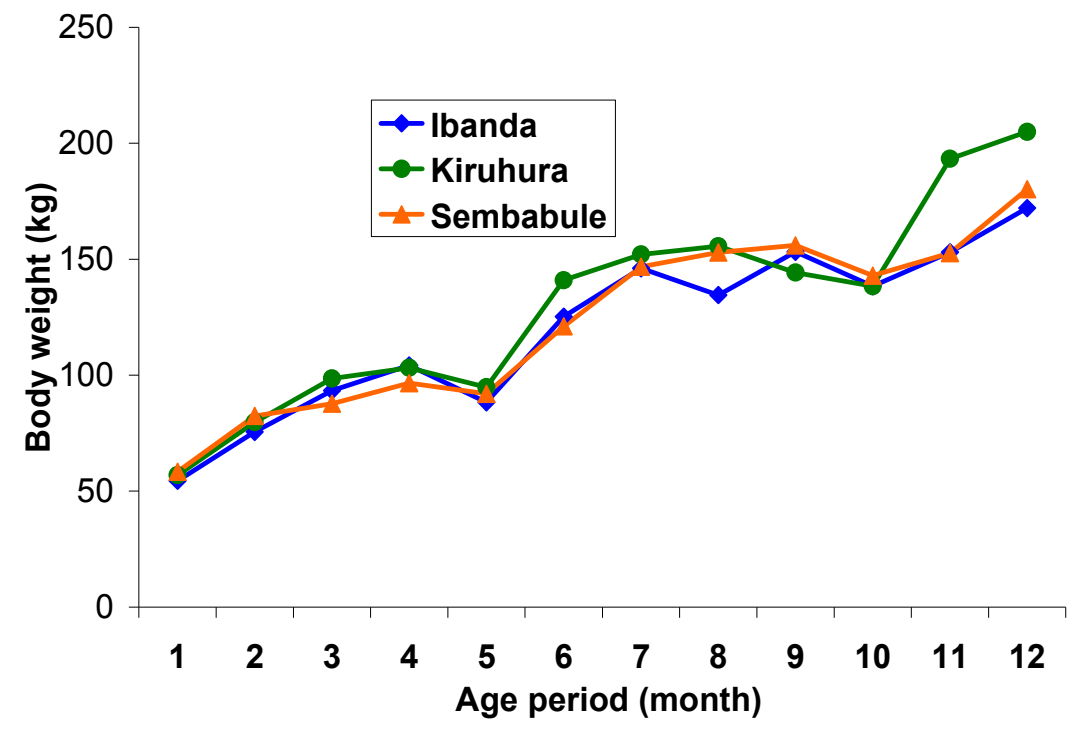

Fig. 7. Comparison of Growth patterns of cattle in Kiruhura, Ibanda and sembabule locations

\subsection{Results of Analysis of Variance ann least square means}

\begin{tabular}{|l|c|c|c|c|c|c|c|c|c|c|c|}
\hline \multirow{3}{*}{ Source } & \multicolumn{9}{|c|}{ Variance for live body weights (kg) } \\
\cline { 2 - 13 } & df & \multicolumn{2}{|c|}{ W1 } & \multicolumn{2}{|c|}{ W2 } & \multicolumn{2}{c|}{ W3 } & \multicolumn{2}{c|}{ W4 } & \multicolumn{2}{c|}{ W5 } \\
\cline { 2 - 13 } & & MS & P & MS & P & MS & P & MS & P & MS & P \\
\hline Breed & 1 & 79.55 & $0.0453^{*}$ & 2339.10 & $0.0001^{* * *}$ & 275.29 & 0.2102 & 237.75 & 0.2959 & 17.01 & 0.7982 \\
\hline Sex & 1 & 8.75 & 0.4973 & 43.64 & 0.3624 & 381.95 & 0.1406 & 1475.94 & 0.0102 & 0.79 & $0.0005^{* * *}$ \\
\hline Season & 1 & 1029.00 & $0.0001^{* * *}$ & 5171.60 & $0.0001^{* * *}$ & 2856.87 & $0.0001^{* * *}$ & 2991.21 & $0.0003^{* * *}$ & 157.99 & 0.4362 \\
\hline Overall & & 354.26 & $0.0001^{* * *}$ & 2257.33 & $<.0001^{* * *}$ & 1144.84 & $0.0004^{* * *}$ & 1392.36 & $0.0005^{* * *}$ & 1101.84 & $0.0066^{* *}$ \\
\hline
\end{tabular}

Key: ${ }^{*}=\mathrm{p}<0.005,{ }^{* *}=\mathrm{p}<0.001,{ }^{* * *}=\mathrm{p}<0.0001, \mathrm{MS}=$ Mean square

Table 1(a). Analysis of variance of On-station MBAZARDI Ankole and Friesian up to 5 months of age

\begin{tabular}{|c|c|c|c|c|c|c|c|c|c|c|c|c|c|}
\hline \multirow{3}{*}{$\begin{array}{l}\text { Sour- } \\
\text { ce }\end{array}$} & \multicolumn{13}{|c|}{ Variance for live body weights (kg) } \\
\hline & & \multicolumn{2}{|c|}{ W6 } & \multicolumn{2}{|c|}{ W7 } & \multicolumn{2}{|c|}{ W8 } & \multicolumn{2}{|c|}{ W9 } & \multicolumn{2}{|c|}{ W10 } & \multicolumn{2}{|c|}{ W11 } \\
\hline & $\mathrm{Df}$ & MS & $\mathrm{P}$ & MS & $\mathrm{P}$ & MS & $\mathrm{P}$ & MS & $\mathrm{P}$ & MS & $\mathrm{P}$ & MS & $\mathrm{P}$ \\
\hline Breed & 2 & 0.038 & 0.3723 & 5419.67 & $0.0003^{\star \star \star *}$ & 2527.08 & $0.0118^{\star \star *}$ & 12810.69 & $<.0001^{* * *}$ & 46552.13 & $0.0001^{* * *}$ & 32136.75 & $0.0001^{\star \star *}$ \\
\hline Sex & 1 & 1889.28 & 0.0081 & 2309.09 & 0.0171 & 354.40 & 0.3410 & 4048.35 & 0.0178 & 8473.26 & $0.0017^{\star \star *}$ & 6430.67 & $0.0004^{* \star *}$ \\
\hline \begin{tabular}{|l}
$\begin{array}{l}\text { Sea- } \\
\text { son }\end{array}$ \\
\end{tabular} & 1 & 281.75 & 0.3016 & 791.83 & 0.1604 & 2626.85 & 0.0102 & 2037.26 & 0.0913 & 530.25 & 0.4267 & 449.60 & 0.3376 \\
\hline $\begin{array}{l}\text { Over- } \\
\text { all }\end{array}$ & & 755.78 & 0.0378 & 3395.64 & $<.0001^{* * *}$ & 2639.55 & $0.0003^{\star \star *}$ & 5081.26 & $0.0001^{\star * *}$ & 17461.11 & $<.0001^{\star * * *}$ & 13080.93 & $<.0001^{* * *}$ \\
\hline
\end{tabular}

Table 1(b). Analysis of variance of On-station MBAZARDI Ankole and Friesian Cattle from 6-11 months of age 


\begin{tabular}{|c|c|c|c|c|c|c|c|c|c|c|c|c|c|}
\hline \multirow{3}{*}{\begin{tabular}{|l} 
Sour- \\
ce
\end{tabular}} & \multicolumn{13}{|c|}{ Variance for live body weights (kg) } \\
\hline & & \multicolumn{2}{|c|}{ W12 } & \multicolumn{2}{|c|}{ W13 } & \multicolumn{2}{|c|}{ W14 } & \multicolumn{2}{|c|}{ W15 } & \multicolumn{2}{|c|}{ W16 } & \multicolumn{2}{|c|}{ W17 } \\
\hline & Df & MS & $\mathrm{P}$ & MS & $\mathrm{P}$ & MS & $\mathrm{P}$ & MS & $\mathrm{P}$ & MS & $\mathrm{P}$ & MS & $\mathrm{P}$ \\
\hline Breed & 2 & 48504.95 & $<.0001^{* \star *}$ & 18953.47 & $<.0001^{\star \star \star \kappa}$ & 35975.63 & $<.0001^{\star \star \star}$ & 58680.75 & $<.0001^{\star \star \star}$ & 27175.23 & $<.0001^{\star \star \star}$ & & \\
\hline Sex & 1 & 6166.57 & $0.0003^{\star \star \star}$ & 3594.66 & $0.0066^{\star \star \star *}$ & 5943.41 & $0.0002^{\star \star \star \star}$ & 6781.15 & $0.0025^{* \star *}$ & 2353.32 & 0.0867 & 3067.20 & 0.0778 \\
\hline $\begin{array}{l}\text { Sea- } \\
\text { son }\end{array}$ & 1 & 6166.57 & 0.5615 & 1366.74 & 0.0902 & 3240.59 & $0.0058^{\star \star \star *}$ & 6365.49 & $34^{* \star *}$ & 3024.48 & 0.0529 & 563.33 & 0.4436 \\
\hline $\begin{array}{l}\text { Over- } \\
\text { all } \\
\end{array}$ & & 18118.15 & $<.0001^{* *}$ & 8791.74 & $<.0001^{\star \star *}$ & 13195.86 & $<.0001^{\star \star \star k}$ & 28507.09 & $<.0001^{\star \star * *}$ & $\mid 13967.80$ & $<.0001^{* \star *}$ & 1557.70 & 0.2029 \\
\hline
\end{tabular}

Table 1(c). Analysis of variance of On-station MBAZARDI Ankole and Friesian Cattle from 12-17 months of age

\begin{tabular}{|c|c|c|c|c|c|c|c|c|c|c|c|c|c|}
\hline \multirow{3}{*}{ Source } & \multicolumn{13}{|c|}{ Variance for live body weights (kg) } \\
\hline & & \multicolumn{2}{|c|}{ W18 } & \multicolumn{2}{|c|}{ W19 } & \multicolumn{2}{|c|}{ W20 } & \multicolumn{2}{|c|}{ W21 } & \multicolumn{2}{|c|}{ W22 } & \multicolumn{2}{|c|}{ W23 } \\
\hline & Df & MS & $\mathrm{P}$ & MS & $\mathrm{P}$ & MS & $\mathrm{P}$ & MS & $\mathrm{P}$ & MS & $\mathrm{P}$ & MS & $\mathrm{P}$ \\
\hline Breed & 2 & & & & & & & & & & & & \\
\hline Sex & 1 & 6.67 & 0.9214 & 1410.67 & 0.2397 & 29040.00 & $0.0011^{* * *}$ & 13005.00 & 0.0548 & 8836.00 & $0.0015^{\star \star \star k}$ & $\begin{array}{c}13689.0 \\
0\end{array}$ & $0.0057^{* * *}$ \\
\hline Season & 1 & 308.17 & 0.5033 & 1.25 & 0.9718 & 3.33 & 0.9695 & 333.33 & 0.7484 & & & & \\
\hline \begin{tabular}{|l|} 
Over- \\
all
\end{tabular} & & 214.58 & 0.7298 & 975.65 & 0.3818 & 18859.29 & $0.0012^{* * *}$ & 9023.00 & 0.0790 & 8836.00 & $0.0015^{\star * * *}$ & 13689.00 & $0.0057^{* * *}$ \\
\hline
\end{tabular}

Table 1(d). Analysis of variance of On-station MBAZARDI Ankole and Friesian Cattle from 18-23 months of age

\begin{tabular}{|l|l|l|c|c|c|c|c|c|c|c|c|c|}
\hline \multirow{2}{*}{ Effect } & \multicolumn{10}{|c|}{ Live body weights (kg) } \\
\cline { 2 - 13 } & & W1 & W2 & W3 & W4 & W5 & W6 & W7 & W8 & W9 & W10 & W11 \\
\hline $\begin{array}{l}\text { Over- } \\
\text { all }\end{array}$ & & & 47.22 & 56.64 & 64.95 & 69.00 & 78.00 & 83.29 & 94.11 & 101.13 & 108.15 & 117.85 \\
\hline Breed & Anko & & 42.25 & 38.41 & 63.69 & 64.12 & 77.02 & 81.21 & 102.01 & 106.57 & 119.17 & 142.49 \\
& le & & \pm 2.24 & \pm 2.23 & \pm 2.67 & \pm 2.57 & \pm 2.57 & \pm 2.42 & \pm 2.63 & \pm 2.48 & \pm 3.34 & \pm 4.08 \\
\cline { 2 - 14 } & Friesi & & 47.25 & 53.47 & 60.03 & 67.29 & 77.02 & 83.79 & 89.81 & 98.01 & 100.55 & 104.75 \\
& an & & \pm 0.71 & \pm 1.09 & \pm 1.83 & \pm 1.86 & \pm 1.62 & \pm 1.56 & \pm 1.92 & \pm 2.15 & \pm 2.71 & \pm 2.81 \\
\hline Sex & Fema & & 44.25 & 46.77 & 63.85 & 69.46 & 82.34 & 86.01 & 99.60 & 103.83 & 114.98 & 131.26 \\
& le & & \pm 1.54 & \pm 1.78 & \pm 2.33 & \pm 2.13 & \pm 1.93 & \pm 1.89 & \pm 2.23 & \pm 2.31 & \pm 2.99 & \pm 3.43 \\
\hline & Male & & 45.25 & 45.1 & 59.87 & 61.94 & 72.47 & 78.99 & 92.22 & 100.75 & 104.74 & 115.98 \\
& & & \pm 1.14 & \pm 1.44 & \pm 2.11 & \pm 2.26 & \pm 2.18 & \pm 1.99 & \pm 2.22 & \pm 2.24 & \pm 3.02 & \pm 3.39 \\
\hline Sea- & Dry & & 39.50 & 34.74 & 55.17 & 59.72 & 76.33 & 81.12 & 98.14 & 106.67 & 106.16 & 121.66 \\
son & & & \pm 1.55 & \pm 2.23 & \pm 3.029 & \pm 2.76 & \pm 2.11 & \pm 1.99 & \pm 2.17 & \pm 2.38 & \pm 3.02 & \pm 3.15 \\
\hline & Wet & & 50.00 & 57.14 & 68.56 & 71.69 & 78.48 & 83.87 & 93.68 & 97.92 & 113.56 & 125.59 \\
& & & \pm 1.10 & \pm 1.09 & \pm 1.59 & \pm 1.75 & \pm 1.99 & \pm 1.92 & \pm 2.34 & \pm 2.27 & \pm 3.06 & \pm 3.74 \\
\hline
\end{tabular}

Table 2(a). Least Square Means (LSM \pm STDERR) for live body weights of On-station MBAZARDI Ankole and Friesian Cattle 
The Growth Performance Evaluation of Cattle

\begin{tabular}{|l|l|c|c|c|c|c|c|c|c|c|}
\hline \multirow{2}{*}{ Effect } & \multicolumn{10}{|c|}{ Live body weights (kg) } \\
\cline { 2 - 11 } & & W12 & W13 & W14 & W15 & W16 & W17 & W18 & W19 & W20 \\
\hline $\begin{array}{l}\text { Over-- } \\
\text { all }\end{array}$ & & 120.28 & 125.39 & 129.23 & 141.21 & 161.38 & 182.23 & 207.50 & 224.67 & 235.71 \\
\hline Breed & Anko- & 142.19 & 149.56 & 143.36 & 156.77 & 183.32 & 193.25 & & & \\
& le & \pm 3.36 & \pm 3.04 & \pm 3.26 & \pm 3.05 & \pm 4.34 & \pm 4.33 & & & \\
& Friesi- & 108.89 & 110.17 & 116.52 & 116.28 & 127.34 & 140.07 & & & \\
& an & \pm 2.27 & \pm 2.31 & \pm 2.82 & \pm 3.31 & \pm 4.50 & \pm 7.44 & & & \\
\hline Sex & Fem- & 132.62 & 137.09 & 136.04 & 144.82 & 164.63 & 172.96 & 220.58 & 222.92 & 244.58 \\
& ale & \pm 2.89 & \pm 2.90 & \pm 3.40 & \pm 3.20 & \pm 4.66 & \pm 5.33 & \pm 8.87 & \pm 7.87 & \pm 10.71 \\
\hline & Male & 118.47 & 122.64 & 123.83 & 128.23 & 146.04 & 160.36 & 201.67 & 223.92 & 229.25 \\
& & \pm 2.69 & \pm 2.56 & \pm 2.79 & \pm 3.19 & \pm 4.07 & \pm 5.62 & \pm 5.61 & \pm 5.31 & \pm 7.01 \\
\hline Sea- & Dry & 123.55 & 128.68 & 133.84 & 143.24 & 165.21 & 174.18 & 206.79 & 227.00 & 236.67 \\
son & & \pm 2.46 & \pm 2.38 & \pm 2.60 & \pm 2.43 & \pm 3.66 & \pm 5.55 & \pm 5.25 & \pm 5.04 & \pm 6.39 \\
\hline & Wet & 127.54 & 131.05 & 126.03 & 129.81 & 145.46 & 159.14 & 215.46 & 219.83 & 237.17 \\
& & \pm 3.26 & \pm 3.16 & \pm 3.65 & \pm 4.06 & \pm 5.33 & \pm 5.66 & \pm 9.51 & \pm 8.39 & \pm 11.80 \\
\hline
\end{tabular}

Table 2(b). Least Square Means (LSM \pm STDERR) for live body weights of On-station MBAZARDI Ankole and Friesian Cattle

\begin{tabular}{|l|l|c|c|c|c|}
\hline \multirow{2}{*}{ Effect } & \multicolumn{5}{|c|}{ Live body weights (kg) } \\
\cline { 2 - 6 } & & W21 & W22 & W23 & W24 \\
\hline Overall & & 240.57 & 235.40 & 277.60 & 298.80 \\
\hline \multirow{2}{*}{ Breed } & Ankole & & & & \\
\cline { 2 - 6 } & Friesian & & & & $310.50 \pm 8.58$ \\
\hline Sex & Female & $268.50 \pm 16.77$ & $263.00 \pm 23.52$ & $287.00 \pm 5.84$ & $252.00 \pm 17.16$ \\
\hline & Male & $202.50 \pm 12.99$ & $212.00 \pm 15.39$ & $240.00 \pm 11.67$ & $281.25 \pm 9.59$ \\
\hline Season & Dry & $236.00 \pm 9.19$ & $242.50 \pm 12.57$ & $263.50 \pm 6.53$ & \\
\hline
\end{tabular}

On-farm growth data

Table 2(c). Least Square Means (LSM \pm STDERR) for live body weights of On-station MBAZARDI Ankole and Friesian Cattle

\begin{tabular}{|c|c|c|c|c|c|c|c|c|c|c|c|c|c|}
\hline \multirow{3}{*}{\begin{tabular}{|l} 
Sour- \\
ce
\end{tabular}} & \multicolumn{13}{|c|}{ Variance for live body weights (kg) } \\
\hline & & \multicolumn{2}{|c|}{ W1 } & \multicolumn{2}{|c|}{ W2 } & \multicolumn{2}{|c|}{ W3 } & \multicolumn{2}{|c|}{ W4 } & \multicolumn{2}{|c|}{ W5 } & \multicolumn{2}{|c|}{ W6 } \\
\hline & $\overline{\text { Df }}$ & MS & $\mathrm{P}$ & MS & $\mathrm{P}$ & MS & $\mathrm{P}$ & MS & $\mathrm{P}$ & MS & $\mathrm{P}$ & MS & $\mathrm{P}$ \\
\hline Breed & 3 & 2276.64 & $<.0001^{* * *}$ & 1994.67 & $0.0003^{* * *}$ & 6595.22 & $<.0001^{* * *}$ & 19748.96 & $<.0001^{* * *}$ & 130.52 & 0.7571 & 1447.86 & $0.0221^{* *}$ \\
\hline Sex & 1 & 38.14 & 0.5969 & 425.06 & 0.2236 & 498.43 & 0.1838 & 315.32 & 0.3924 & 49.34 & 0.7459 & 1.07 & 0.9606 \\
\hline Season & 1 & . & . & . & . & 10.79 & 0.8441 & 3337.52 & $0.0059^{* * *}$ & 1062.89 & 0.1341 & 5964.76 & 0.0003 \\
\hline $\begin{array}{l}\text { Distr- } \\
\text { ict }\end{array}$ & 3 & 156.65 & 0.3181 & 338.84 & 0.3069 & 426.42 & 0.2212 & 651.41 & 0.2220 & 401.14 & 0.4267 & 4726.64 & $<.0001^{* * *}$ \\
\hline \begin{tabular}{|l|} 
Over- \\
all
\end{tabular} & & 52.01 & & 64.49 & & 74.94 & & 82.23 & & 87.68 & & 101.56 & \\
\hline
\end{tabular}

Table 3(a). Analysis of variance of On-farm Kiruhura, Ibanda and Sembabule Ankole, Boran and Friesian crosses up to 6 months of age 


\begin{tabular}{|c|c|c|c|c|c|c|c|c|c|c|c|c|c|}
\hline \multirow{3}{*}{ Source } & \multicolumn{13}{|c|}{ Variance for live body weights (kg) } \\
\hline & & \multicolumn{2}{|c|}{ W7 } & \multicolumn{2}{|c|}{ W8 } & \multicolumn{2}{|c|}{ W9 } & \multicolumn{2}{|c|}{ W10 } & \multicolumn{2}{|c|}{ W11 } & \multicolumn{2}{|c|}{ W12 } \\
\hline & $\overline{\text { Df }}$ & MS & $\mathrm{P}$ & MS & $\mathrm{P}$ & MS & $\mathrm{P}$ & MS & $\mathrm{P}$ & MS & $\mathrm{P}$ & MS & $\mathrm{P}$ \\
\hline Breed & 3 & 43394.75 & $<.0001^{\star \star \star *}$ & 18738.28 & $<.0001^{*-* *}$ & 5941.96 & $0.0123^{* *}$ & 3739.08 & 0.0140 & 249.60 & 0.6822 & 344.70 & 0.7232 \\
\hline Sex & 1 & 67.89 & 0.7715 & 6.69 & 0.9257 & 1718.59 & 0.2481 & 446.099 & 0.4987 & 202.58 & 0.7122 & 2870.00 & 0.1073 \\
\hline Season & 1 & \begin{tabular}{|l|}
1604.24 \\
\end{tabular} & 0.1594 & 268.49 & 0.5548 & 2258.80 & 0.1861 & 1322.24 & 0.2462 & 2078.51 & 0.2411 & 686.45 & 0.4248 \\
\hline $\begin{array}{l}\text { Distri- } \\
\mathrm{ct}\end{array}$ & 3 & 524.30 & 0.5217 & 5809.68 & $0.0007^{* * * *}$ & 514.69 & 0.6677 & 158.45 & 0.8484 & 2796.13 & 0.1622 & 3032.60 & 0.0687 \\
\hline $\begin{array}{l}\text { Over- } \\
\text { all }\end{array}$ & & 120.12 & & 124.24 & & 136.39 & & 145.88 & & 157.20 & & 170.09 & \\
\hline
\end{tabular}

Table 3(b). Analysis of variance of On-farm Kiruhura, Ibanda and Sembabule Ankole, Boran and Friesian crosses from 7-12 months of age

\begin{tabular}{|c|c|c|c|c|c|c|c|c|c|}
\hline \multirow[t]{2}{*}{ Effect } & \multicolumn{9}{|c|}{ Live body weights (kg) } \\
\hline & & W1 & W2 & W3 & W4 & W5 & W6 & W7 & W8 \\
\hline $\begin{array}{l}\text { Over- } \\
\text { all }\end{array}$ & & 52.01 & 64.49 & 74.94 & 82.23 & 87.68 & 101.56 & 120.12 & 124.24 \\
\hline \multirow[t]{4}{*}{ Breed } & Ankole & $54.97 \pm 2.69$ & $85.77 \pm 6.89$ & $118.75 \pm 9.85$ & $87.79 \pm 6.13$ & $95.94 \pm 9.90$ & $132.33 \pm 8.92$ & $143.66 \pm 8.69$ & $137.74 \pm 10.72$ \\
\hline & $\begin{array}{c}\text { Boran } \\
\text { cross }\end{array}$ & $54.09 \pm 3.66$ & $61.36 \pm 4.35$ & $68.35 \pm 9.12$ & $91.04 \pm 7.44$ & $90.56 \pm 5.83$ & $113.11 \pm 8.21$ & $105.49 \pm 10.93$ & $116.85 \pm 7.67$ \\
\hline & Boran & $69.38 \pm 2.94$ & $110.01 \pm 17.19$ & $119.51 \pm 8.47$ & $150.23 \pm 6.05$ & & $156.71 \pm 22.11$ & $233.66 \pm 9.27$ & $215.16 \pm 11.17$ \\
\hline & \begin{tabular}{|c|}
$\begin{array}{c}\text { Friesian } \\
\text { cross }\end{array}$ \\
\end{tabular} & $47.86 \pm 1.10$ & $59.78 \pm 2.63$ & $66.15 \pm 4.65$ & $76.14 \pm 6.05$ & $88.64 \pm 2.87$ & $114.12 \pm 5.19$ & $110.48 \pm 4.12$ & $120.90 \pm 3.21$ \\
\hline \multirow[t]{2}{*}{ Sex } & Female & $57.10 \pm 1.53$ & $82.04 \pm 4.87$ & $96.95 \pm 5.88$ & $102.97 \pm 3.05$ & $92.45 \pm 4.15$ & $129.21 \pm 7.87$ & $149.33 \pm 4.76$ & $147.41 \pm 4.65$ \\
\hline & Male & $56.05 \pm 2.04$ & $76.42 \pm 6.30$ & $89.43 \pm 6.95$ & $99.63 \pm 4.42$ & $90.97 \pm 5.27$ & $128.92 \pm 9.24$ & $147.32 \pm 7.32$ & $147.92 \pm 6.33$ \\
\hline \multirow{2}{*}{$\begin{array}{l}\text { Sea- } \\
\text { son }\end{array}$} & Dry & & & $92.19 \pm 9.78$ & $107.24 \pm 4.60$ & $95.34 \pm 5.29$ & $147.87 \pm 11.94$ & $153.18 \pm 7.13$ & $149.25 \pm 5.94$ \\
\hline & Wet & $56.58 \pm 1.50$ & $79.23 \pm 5.14$ & $94.19 \pm 4.75$ & $95.36 \pm 3.03$ & $88.09 \pm 4.27$ & $110.27 \pm 6.31$ & $143.46 \pm 5.02$ & $146.08 \pm 5.02$ \\
\hline \multirow{3}{*}{$\begin{array}{l}\text { Distr- } \\
\text { icts }\end{array}$} & Ibanda & $54.48 \pm 2.49$ & $75.57 \pm 6.09$ & $93.36 \pm 7.19$ & $104.21 \pm 4.14$ & $88.34 \pm 5.33$ & $125.22 \pm 9.31$ & $146.09 \pm 6.62$ & $134.48 \pm 6.19$ \\
\hline & \begin{tabular}{|l|} 
Kiruhura \\
\end{tabular} & $56.86 \pm 1.86$ & $79.72 \pm 6.16$ & $98.53 \pm 6.67$ & $103.16 \pm 4.27$ & $94.82 \pm 5.35$ & $140.96 \pm 8.76$ & $152.09 \pm 6.46$ & $155.60 \pm 6.35$ \\
\hline & $\begin{array}{c}\text { Sembab } \\
\text { ule }\end{array}$ & $58.39 \pm 1.67$ & $82.41 \pm 4.99$ & $87.68 \pm 6.12$ & $96.54 \pm 4.17$ & $91.98 \pm 4.27$ & $121.02 \pm 7.75$ & $146.77 \pm 6.07$ & $152.91 \pm 5.29$ \\
\hline
\end{tabular}

Table 4(a). Least Square Means (LSM \pm STDERR) for live body weights of On farmKiruhura, Ibanda and Sembabule Ankole, Boran and Friesian crosses

\begin{tabular}{|l|c|c|c|c|c|}
\hline \multirow{2}{*}{ Effect } & \multicolumn{5}{|c|}{ Live body weights (kg) } \\
\cline { 2 - 6 } & & W9 & W10 & W11 & W12 \\
\hline \multirow{3}{*}{ Breed } & & 136.39 & 145.88 & 157.20 & 170.09 \\
& Ankole & $183.23 \pm 18.07$ & $175.09 \pm 16.39$ & & $197.58 \pm 26.92$ \\
\cline { 2 - 6 } & Boran cross & $141.27 \pm 14.34$ & $101.89 \pm 19.07$ & $171.90 \pm 25.35$ & $171.18 \pm 25.36$ \\
\cline { 2 - 6 } & Boran & & $144.89 \pm 32.93$ & & $188.42 \pm 8.86$ \\
\cline { 2 - 6 } & Friesian cross & $128.89 \pm 6.39$ & $145.68 \pm 10.44$ & $160.69 \pm 12.20$ & $172.32 \pm 13.03$ \\
\hline Sex & Female & $157.72 \pm 9.38$ & $136.22 \pm 10.75$ & $169.83 \pm 14.28$ & $199.12 \pm 18.48$ \\
\hline \multirow{2}{*}{ Season } & Male & $144.55 \pm 12.48$ & $147.57 \pm 19.53$ & $162.77 \pm 19.97$ & $181.05 \pm 14.55$ \\
\hline & Dry & $158.75 \pm 13.03$ & $133.19 \pm 17.53$ & $178.69 \pm 20.64$ & $190.39 \pm 15.33$ \\
\hline Districts & Wet & $143.52 \pm 8.66$ & $150.59 \pm 12.69$ & $153.89 \pm 14.61$ & $172.06 \pm 17.05$ \\
\hline & Ibanda & $153.22 \pm 13.51$ & $138.32 \pm 15.62$ & $152.99 \pm 17.05$ & $204.89 \pm 19.62$ \\
\hline & Kiruhura & $144.25 \pm 13.25$ & $138.32 \pm 14.78$ & $193.29 \pm 24.31$ & $180.22 \pm 13.72$ \\
\hline
\end{tabular}

Table 4(b). Least Square Means (LSM \pm STDERR) for live body weights of On farm Kiruhura, Ibanda and Sembabule Ankole, Boran and Friesian crosses 


\section{Conclusion and recommendations}

The study concludes that the factors that affect growth performance among on-station and on-farm cattle breeds include: breed, sex of the animal and seasonal variation. The study revealed that twinning in cattle was a rare occurrence. The study demonstrated that Boran cattle performed much better than the rest of other breeds in terms of growth followed by Ankole, Friesian cross and Boran cross respectively. It was found that the performance of cattle breeds did not vary significantly $(\mathrm{p}>0.005)$ among the different geographical areas of Mbarara, Kiruhura, Ibanda and Sembabule except months six $(\mathrm{p}<005)$ and months eight $(p<0.05)$. The genotypes of the breeds were very important in performance evaluations. It was however noted that, husbandry practices related to feeding, deworming, spraying, mineral supplementation and other disease control measures were paramount in promoting the full potential of the breeds. Other important factors to consider included environmental conditions e.g. temperature, humidity etc. The study recommended genetic characterisation of the cattle breeds. Guidelines for appropriate Ankole and Friesian breeding and management practices developed and disseminated.

\section{Acknowledgement}

The following are acknowledged for their contributions in getting this work done. National Agriculture Research Organization (NARO) for funding this field based research activities. The farmers contributed immensely by availing cattle to be used in the research study and willingly accepting to cooperate during the data gathering process which most times was strenuous. Extension workers from Kiruhura, Ibanda and Sembabule districts are applauded.

\section{References}

Anonymous (1981). Dairy cattle. Retrieved from http:/ / www.nap.edu/openbook.php?isbn

Asimwe L and Kifaro G C 2007. Effect of breed, season, year and parity on reproductive performance of dairy cattle under smallholder production system in Bukoba district, Tanzania. Livestock Research for Rural Development. Volume 19, article \#152 Retrieved June 30, 2010 from http://www.lrrd.org/lrrd19/10/asim1952.htm

Fisher, A.D., Knight, T.W., Cosgrove, G.P., Death, A.F., Anderson, C.B., Duganzich, D.M., Matthews, L.R (2001). Effects of surgical or banding castration on stress responses and behaviour of bulls. The Journal of the Australian Veterinary Association. Volume 79, Issue 4 , Pages279 - 2842001

Katyega P M 1998.Performance of Jerseys on the slopes of Mount Meru. World Animal Review 65: 24-30

Kifaro G C 1984. Production efficiency of Bos taurus cattle in Mbeya region. Msc. Thesis . Sokoine University of Agriculture. Morogoro, Tanzania. pp 52-95.

Kiwuwa G H, Trail J C M, Kurtu M Y, Worku G, Anderson F M and Durkin J 1983. Crossbred dairy cattle productivity in Arsi region, Ethiopia (Research report No. 11, ILCA, Addis Ababa, Ethiopia). 1-29. 
Krupa, E., Oravcová, M., Polák, P., Huba, J.,Krupová., (2005). Factors affecting growth traits of beef cattle breeds raised in Slovakia. Czech J. Anim.Sci.,50, 2005 (1): 14-21

Kugonza, D.R., Mwai, O.A., et al. 2005. Ankole Cattle Breed of Uganda: Functions and Criteria Used in Identification, Selection and Parentage Assignment by Herdsmen. Rare Breeds International (RBI) Conservation of Domestic Animal Genetic Resources Global Conference Proceedings 6:18 (Abstract).

Mc Donald P, Edward R A, Greenhalgh J F D and Morgan C A 2002 Animal Nutrition. $6^{\text {th }}$ Edition. Pearson Education Limited, Edinburgh Gate. Harlow 693 pp

Moran J 2002 . Calf rearing. A practical guide. $2^{\text {nd }}$ edition. CSIRO publishing. Collingwood Victoria. $228 \mathrm{pp}$

Ndumu, D., Baumung, R., et al. 2006. Performance and fitness traits versus phenotypic appearance: a novel approach to identify selection criteria for indigenous breeds. Deutscher Tropentag, Conference on International Agricultural Research for Development, Bonn-University of Bonn, October 11-13, 2006. www.tropentag.de/2006/abstracts/ full/151.pdf

Ndumu, D., Baumung, R., et al. 2008. Performance and fitness traits versus phenotypic appearance: A novel approach to identify selection criteria for indigenous breeds. Livestock Science 113: 234-24.

Nsubuga, H.S.K. 1996. Small Ruminants: Goats and sheep in Uganda. In: Lebbie, H.B. and Kagwini,E.(Eds).Small Ruminant Research Development in Africa. Proceedings of the third biennial Conference of the African small ruminant research network.UICC, Kampala,Uganda 5-9 December 1994. Pp. 1-4.

Oluka, J (2006). On-farm Comparative Perfomance evaluation of selected indigenous, Exotic and Crossbred Goat Populations in Uganda. PhD thesis.The Royal Veterinary and Agricultural University Copenhagen, Denmark.

Petersen, P.H., Ndumu, D.B., et al. 2003. Characteristics of Ankole Longhorn cattle and their production environments in South Western Uganda: milk offtake and body measurements. Animal Genetic Resources Information 34: 1-9.

Said R, Bryant M J and Msechu J K K (2001). Growth and survival of crossbred beef cattle in Tanzania. Tanzania society for Animal production proceedings, volume 28, 2001.

Tuah A K and Yaa Nyamaa Danso 1985. Preliminary studies on the performance and productivity indices of N'Dama and West African shorthorn cattle in Ghana. Tropical Animal Health production, 17, 114- 120.

Twinamasiko, N.I. 2001. Dairy Production. In: Agriculture in Uganda. Livestock and Fisheries. Mukiibi, J.K. (ed). Fountain Publishers / CTA / NARO 4: 18-42.

Vial, V. E. and More O'Ferrall G. J. (1965). The Effects of Breed, Sex, Season and Age of Dam on the Birth Weight of Dairy and Crossbred Calves and their Growth during the First Seven Days of Age .Irish Journal of Agricultural Research, Vol. 4, No. 2 (Oct., 1965), pp. 223-230

Wurzinger, M., Ndumu, D., et al. 2007. Comparison of production systems and selection criteria of Ankole cattle by breeders in Burundi, Rwanda, Tanzania and Uganda. Tropical Animal Health and Production 38: 571-581. 


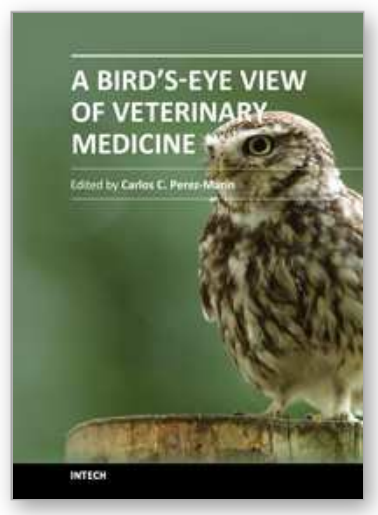

\author{
A Bird's-Eye View of Veterinary Medicine \\ Edited by Dr. Carlos C. Perez-Marin
}

ISBN 978-953-51-0031-7

Hard cover, 626 pages

Publisher InTech

Published online 22, February, 2012

Published in print edition February, 2012

Veterinary medicine is advancing at a very rapid pace, particularly given the breadth of the discipline. This book examines new developments covering a wide range of issues from health and welfare in livestock, pets, and wild animals to public health supervision and biomedical research. As well as containing reviews offering fresh insight into specific issues, this book includes a selection of scientific articles which help to chart the advance of this science. The book is divided into several sections. The opening chapters cover the veterinary profession and veterinary science in general, while later chapters look at specific aspects of applied veterinary medicine in pets and in livestock. Finally, research papers are grouped by specialisms with a view to exploring progress in areas such as organ transplantation, therapeutic use of natural substances, and the use of new diagnostic techniques for disease control. This book was produced during World Veterinary Year 2011, which marked the 250th anniversary of the veterinary profession. It provides a fittingly concise and enjoyable overview of the whole science of veterinary medicine.

\title{
How to reference
}

In order to correctly reference this scholarly work, feel free to copy and paste the following:

Charles Lagu, Robert Nsubuga Mutaka, James Oluka, Steven Byenkya, Betty Laura Ayoo, Immaculate Nabukenya and Proscovia Ntakyo (2012). The Growth Performance Evaluation of Cattle Breeds in the South Western Agro-Ecological Zone (SWAEZ) of Uganda, A Bird's-Eye View of Veterinary Medicine, Dr. Carlos C. Perez-Marin (Ed.), ISBN: 978-953-51-0031-7, InTech, Available from: http://www.intechopen.com/books/abird-s-eye-view-of-veterinary-medicine/growth-performance-evaluation-of-cattle-breeds-in-the-south-westernagro-ecological-zone-swaez-of-ug

\section{INTECH}

open science | open minds

\section{InTech Europe}

University Campus STeP Ri

Slavka Krautzeka 83/A

51000 Rijeka, Croatia

Phone: +385 (51) 770447

Fax: +385 (51) 686166

www.intechopen.com

\section{InTech China}

Unit 405, Office Block, Hotel Equatorial Shanghai

No.65, Yan An Road (West), Shanghai, 200040, China 中国上海市延安西路65号上海国际贵都大饭店办公楼 405 单元

Phone: +86-21-62489820

Fax: $+86-21-62489821$ 
(C) 2012 The Author(s). Licensee IntechOpen. This is an open access article distributed under the terms of the Creative Commons Attribution 3.0 License, which permits unrestricted use, distribution, and reproduction in any medium, provided the original work is properly cited. 